\title{
Review \\ Ischemic Stroke and Heart Failure: Facts and Numbers. An Update
}

\author{
Anush Barkhudaryan ${ }^{1,2}$, Wolfram Doehner ${ }^{3,4,5}$ (i) and Nadja Scherbakov $3,4,5, *$ (i) \\ 1 Department of Cardiology, Clinic of General and Invasive Cardiology, University Hospital No 1, \\ Yerevan State Medical University, Yerevan 0025, Armenia; dran_bar@yahoo.com \\ 2 Cardiovascular Research Institute Basel, University Hospital Basel, 4056 Basel, Switzerland \\ 3 BIH Center for Regenerative Therapies (BCRT), Charité-Universitätsmedizin Berlin, 13353 Berlin, Germany; \\ wolfram.doehner@charite.de \\ 4 Department of Cardiology, Campus Virchow, Charité-Universitätsmedizin Berlin, DZHK (German Center for \\ Cardiovascular Research), Partner Site Berlin, 13353 Berlin, Germany \\ 5 Center for Stroke Research Berlin (CSB), Charité-Universitätsmedizin Berlin, Augustenburger Platz 1, \\ 13353 Berlin, Germany \\ * Correspondence: nadja.scherbakov@charite.de
}

Citation: Barkhudaryan, A.;

Doehner, W.; Scherbakov, N. Ischemic Stroke and Heart Failure: Facts and Numbers. An Update. J. Clin. Med. 2021, 10, 1146. https://doi.org/ $10.3390 / \mathrm{jcm} 10051146$

Academic Editor: Peter Sporns

Received: 29 January 2021

Accepted: 27 February 2021

Published: 9 March 2021

Publisher's Note: MDPI stays neutral with regard to jurisdictional claims in published maps and institutional affiliations.

Copyright: (c) 2021 by the authors. Licensee MDPI, Basel, Switzerland. This article is an open access article distributed under the terms and conditions of the Creative Commons Attribution (CC BY) license (https:/ / creativecommons.org/licenses/by/ $4.0 /)$.

\begin{abstract}
Heart failure (HF) is a severe clinical syndrome accompanied by a number of comorbidities. Ischemic stroke occurs frequently in patients with $\mathrm{HF}$ as a complication of the disease. In the present review, we aimed to summarize the current state of research on the role of cardio-cerebral interactions in the prevalence, etiology, and prognosis of both diseases. The main pathophysiological mechanisms underlying the development of stroke in HF and vice versa are discussed. In addition, we reviewed the results of recent clinical trials investigating the prevalence and prevention of stroke in patients with HF.
\end{abstract}

Keywords: HFrEF; HFpEF; ischemic stroke; risk factor; cardio-cerebral interactions; stroke prevention

\section{Introduction}

Heart failure (HF) is a complex clinical syndrome with a high prevalence of diagnosed cases worldwide, described by ventricular systolic or diastolic dysfunction associated with a high rate of mortality and morbidity. A number of comorbidities, including diabetes mellitus, coronary artery disease (CAD), and cerebrovascular diseases, may complicate the course of HF. Among them, acute ischemic stroke may lead to life-threatening complications such as acute decompensation of chronic HF and have a negative impact on further management, as well as on the clinical outcome of patients suffering from HF. On the other hand, chronic HF is considered one of the major risk factors associated with the occurrence and unfavorable clinical outcome after ischemic stroke [1,2].

Recently, a new classification of the European Society of Cardiology (ESC) of the diagnosis of HF based on the left ventricular ejection fraction (LVEF), clinical signs of HF, and structural and functional myocardial changes has received growing attention $[3,4]$. This classification includes HF with preserved ejection fraction (HEpEF, LVEF > 50\%), HF with mid-range ejection fraction (HFmrEF, LVEF 40-49\%), and HF with reduced ejection fraction ( $\mathrm{HFrEF}, \mathrm{LEVF}<40 \%$ ). The current review presents an update on recent epidemiological data, the pathophysiological mechanisms of heart-brain interaction, as well as the advancements in the prevention and treatment of acute ischemic stroke in the setting of chronic HF.

\section{The Prevalence of Ischemic Stroke in Heart Failure}

With the global prevalence of over 104 million cases in 2017 and with an annual incidence rate of 12 million cases, ischemic stroke is considered one of the global disease burdens and a leading cause of death and disability in adult age [5]. Patients with HF have 
a 2- to 5-fold increased risk of stroke [6-8]. In particular, a higher prevalence of ischemic stroke is observed in patients with chronic HF compared to the general population (8-11\% vs. 1\%) [9]. The stroke rate increases stepwise from $1.3 \%$ to $3.5 \%$ dependent on the New York Heart Association (NYHA) functional class of HF. Recent analyses of the Swedish Heart Failure (SwedeHF) Registry study suggested no significant differences in stroke prevalence between the HFrEF, HFmrEF, and HFpEF phenotypes; however, the risk of stroke was higher in older patients and those with atrial fibrillation (AF) $[10,11]$. This is expectable, since aging is associated with a higher prevalence of cardiac arrhythmias, including AF $[12,13]$. Depending on study designs and patient cohorts, the presence of AF accounts for 2-29\% of stroke without a significant difference between HFpEF and HFrEF $[14,15]$. Therefore, according to the current ESC Guidelines, the presence of HF and older age ( $>65$ years), evaluated by the CHA2-DS2-VASc score (congestive heart failure; hypertension; age $\geq 75$, diabetes mellitus; stroke/transitory ischemic attack (TIA); vascular disease, age 65-74; sex category) [16] with $\geq 2$ points, respectively, requires a prescription of continuous oral anticoagulation in patients with $\mathrm{AF}$ [17].

\section{Etiology of Stroke and Risk Factors in Heart Failure}

Previously, several classifications of stroke etiology have been proposed [18]. The common clinical one, the Trial of Org 10172 in Acute Stroke Treatment (TOAST), includes five subtypes of ischemic stroke according to the etiology of stroke: cardioembolic, largeartery atherosclerosis, lacunar or small-vessel occlusion, stroke of other determined etiology, and stroke of undetermined etiology [19]. Among these, the cardioembolic subtype of stroke refers to the classical cardiac origin of embolus due to AF, myocardial infarction, endocarditis, cardiac tumors, or valvular heart disease, and accounts for $20-30 \%$ of all ischemic stroke cases $[20,21]$. In recent years, the subtype of stroke of undetermined etiology has been intensively studied, and an alternative diagnosis of embolic stroke of undetermined source (ESUS) has been proposed [22]. The studies investigating ESUS identified the presence of paroxysmal or persistent $\mathrm{AF}$, patent foramen ovale (PFO), atrial cardiomyopathy, and a large artery plaque underling the development of this type of cryptogenic stoke [23-25] (Figure 1).

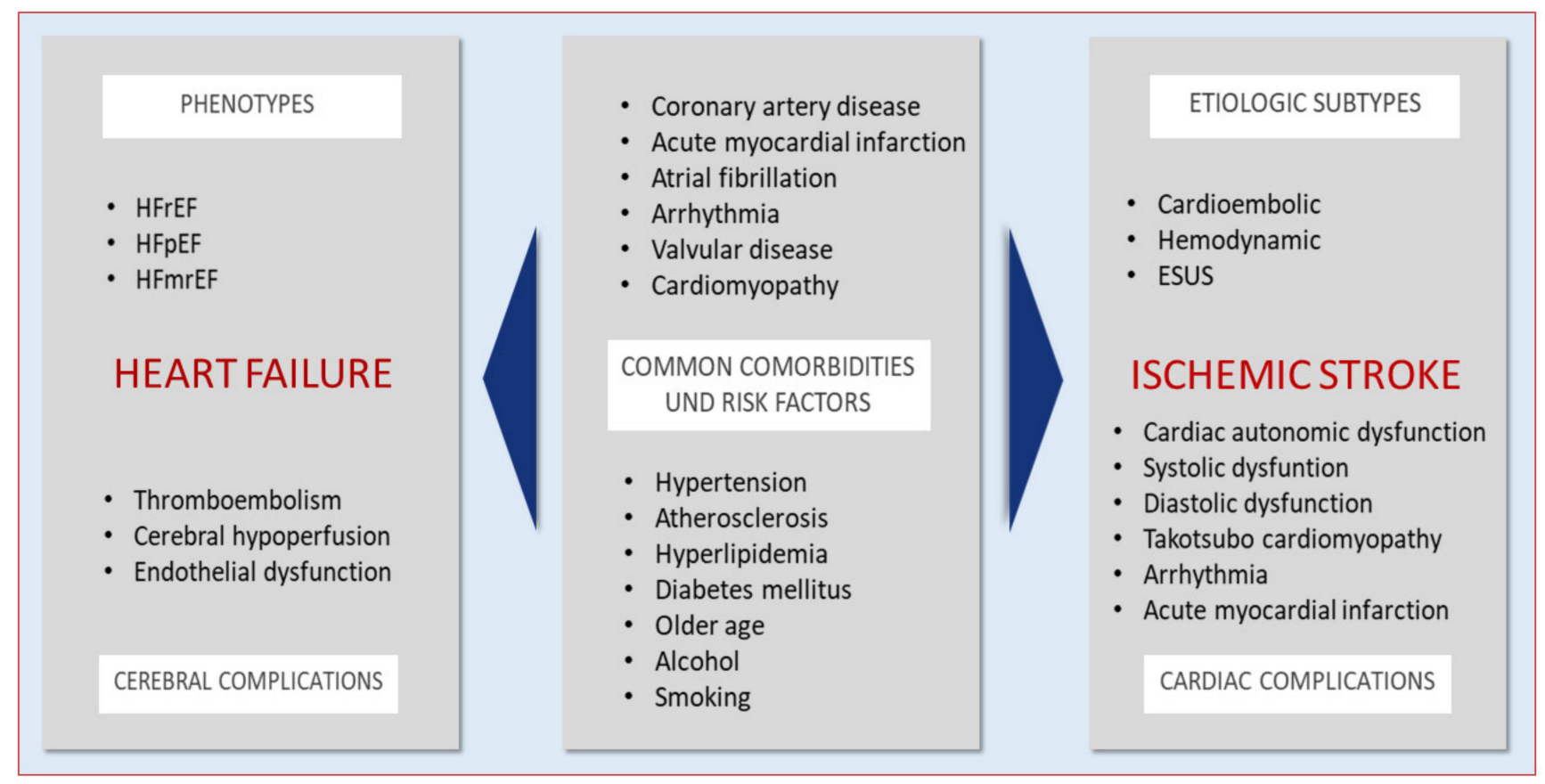

Figure 1. The comorbidities and risk factors in ischemic stroke and heart failure. 
Previously, a relationship between the subtypes of stroke and HF etiology has been shown [26]. In particular, in patients with sinus rhythm, valvular heart disease and dilated cardiomyopathy were mainly associated with cardioembolic stroke, whereas HF developing due to $\mathrm{CAD}$ or arterial hypertension has been related to the lacunar or large artery atherosclerotic strokes. However, the cerebrovascular thromboembolism remains the most frequently observed etiological factor, leading to the development of ischemic stroke in patients with chronic HF, including those with CAD [27,28]. Patients with HFrEF are known to possess a prothrombotic state due to platelet hyperactivity, increased thrombin generation, and impaired fibrinolysis $[29,30]$. The presence of a hypercoagulable state has also been reported in patients with HFpEF [31]. The endothelial dysfunction observed in patients with chronic HF results in decreased endothelium-derived nitric oxide generation and reduced microvascular reactivity of the myocardium, leading to subendocardial damage that finally promotes the development of thromboembolic complications $[5,32,33]$. Furthermore, pathological ventricular remodeling, including dilatation of LV and/or left atrium (LA), LV akinesia, dyskinesia, or aneurysm may also contribute to the stasis of blood flow and thus, promote thrombus formation $[34,35]$. These pathological conditions represent the Virchow's triad of hypercoagulable activation [36,37]. The main pathophysiological mechanisms driving the progression of $\mathrm{HFrEF}$, including activation of sympathetic and renin-angiotensin-aldosterone systems, as well as a systemic inflammation, further increase the risk of stroke in these patients.

Another subtype of ischemic stroke caused by cerebral hypoperfusion has been previously proposed as a hemodynamic stroke [38]. Several factors, including large artery stenosis and occlusion due to atherosclerotic disease, hypotension, or anemia, may underlie the development of this subtype of stroke [38-40]. The decrease in cerebral blood flow may be further compromised due to the reduced cardiac output in patients with HF in the presence of large artery stenosis [41,42]. The cerebral hypoperfusion leads to a decrease in blood flow to the areas of brain supplied by deep arteries lacking collateral flow, which makes them vulnerable to ischemic damage [21], vascular dementia [43,44], silent or subclinical stroke, and cognitive impairment $[14,45,46]$.

\section{Cardio-Cerebral Interactions after Acute Stroke}

The development of cardiac complications in the acute and subacute phases of stroke, including structural myocardial injury, revealed by electrocardiographic changes, elevation of biomarkers, such as cardiac Troponin T (cTnT) or natriuretic peptides, as well as acute coronary syndrome, is frequently observed after stroke and may deteriorate the prognosis of stroke patients [47-49]. The Troponin Elevation in Acute Ischemic Stroke (TRELAS) sub-study showed that $25 \%$ of patients with acute stroke and elevated plasma cTn levels required a percutaneous coronary intervention (PCI) due to the presence of culprit lesion detected by coronary angiography [50]. The elevated levels of cTn were associated with adverse outcome 3 months after stroke [51]. Furthermore, the development of acute myocardial infarction (AMI) during a short- and long-term follow-up after acute ischemic stroke has been frequently reported [52-54]. In particular, the presence of diabetes mellitus, congestive $\mathrm{HF}$, and arterial hypertension in patients with stroke has been associated with the development of AMI 1-5 years after the acute cerebrovascular event and related to an increased post stroke mortality [55]. In addition, Takotsubo cardiomyopathy, with a prevalence of $0.4-1.2 \%$, has been reported after acute ischemic stroke, however more commonly in patients with hemorrhagic stroke [56,57]. Thus, the occurrence of stroke-associated cardiac complications may be summarized under stroke-heart syndrome [58].

The pathophysiological mechanisms of stroke-heart syndrome have not been sufficiently investigated yet. One of the underlying pathways is the development of acute autonomic dysfunction. A recent experimental study reported a reduction in LVEF, myocardial fractional shortening, and heart rate after acute cerebral ischemia induced by middle cerebral artery occlusion (MCAO) in mice, which was accompanied by elevation of cTnT levels [59]. In addition, impaired catecholamine homeostasis was confirmed by elevated 
levels of norepinephrine. The results of a previous clinical study revealed a mechanistic link between the central autonomic dysregulation evaluated by central sleep apnea and peripheral endothelial dysfunction in acute stroke [60]. Interestingly, after 1 year follow-up, a disappearance of the central sleep apnea was observed in patients with normalized endothelial function and left-sided stroke. Indeed, experimental and clinical studies suggest a lateralization of the autonomic regulation with a primary involvement of right insular regions. The role of the insular cortex in the regulation of cardiovascular function has been previously reported, showing that right hemisphere insular cortex stroke leads to an increase in sympathetic activity [61,62]. Another study, investigating the impact of cardiac autonomic tone on the clinical outcome in subacute stroke, showed an association between the depressed heart rate variability and impaired functional outcome after post stroke neurological rehabilitation [63]. Thus, central autonomic dysfunction may contribute to the development of cardiovascular complications in patients with acute stroke leading to an adverse clinical outcome.

Cardio-cerebral interactions in the setting of HF have also been investigated in previous studies. The main pathophysiological mechanisms, including increased inflammation, cerebral hypoperfusion, neurohormonal activation, and decreased thiamine levels, contribute to the development of cardiocerebral syndrome characterized by structural changes of the brain leading to cognitive impairment in patients with HF [41]. An association between brain structural damage and decreased blood flow has been previously reported in patients with HF [64]. In another study, a decrease in gray matter density in the areas of hippocampus, precuneus, and frontomedian cortex and increased N-terminal pro-Btype natriuretic peptide (NT-proBNP) levels have been shown in HFrEF [65]. Thus, the heart-brain interaction in the setting of acute stroke and HF mutually contributes to the development of myocardial dysfunction and cerebral impairment, respectively, requiring the administration of treatment of these complications to improve quality of life, survival, and clinical outcome in these patient cohorts.

\section{The Impact of Heart Failure and Atrial Fibrillation on the Clinical Outcome of Ischemic Stroke}

\subsection{Heart Failure}

The presence of chronic HF has a prognostic significance in patients with acute stroke. In particular, increased levels of natriuretic peptides indicating the severity of chronic HF and decreased LVEF have been shown to be risk factors for development of stroke in patients with HF without AF $[35,66]$. In the physiologic condition, an elevated LV filling pressure per se leads to an increased contractility (Frank-Starling mechanism); however, in the setting of HF, this mechanism is impaired, the stroke volume decreases subsequently resulting in cerebral hypoperfusion [1]. In a population-based study, including over 7500 participants, the risk of stroke in patients was particularly high (more than five-fold increase) during the first months after diagnosis of HF but attenuated over time [67]. The findings of another study showed that acute decompensation of chronic HF was regarded as an independent predictor of adverse functional outcome in patients with ischemic stroke [68]. In addition, reduced LVEF has been associated with adverse outcome after cardioembolic stroke [69]. Furthermore, the relationship between decreased LVEF and poor neurological outcome (modified Rankin Scale, mRS $\geq 3$ ) has been previously reported in patients with ischemic stroke [1]. Previous clinical studies have shown that apart from clinically manifested strokes, silent strokes were more prevalent in patients with HF compared to subjects without the disease [70,71].

\subsection{Atrial Fibrillation}

The most frequently observed arrhythmia is a non-valvular AF which increases the risk of stroke by $4-5$ times [72]. The presence of AF in chronic HF is considered one of the major risk factors of acute ischemic stroke $[73,74]$ associated with an increased post stroke mortality and physical disability [75-77]. In a recent study in patients with acute 
ischemic stroke, an increased risk of in-hospital mortality in patients with HF, regardless of the coexistence of AF, has been reported. However, the risk of stroke recurrence was doubled in patients with AF and HF, as opposed to patients with only HF [78]. These findings are consistent with the results of previous trials showing a higher risk of stroke recurrence in patients with these comorbidities $[79,80]$. In the Aliskeren Trial on Acute Heart Failure Outcomes (ASTRONAUT) sub-study, patients with atrial fibrillation/flutter (AFF) and HFrEF hospitalized with acute HF showed significantly higher rates of fatal stroke in contrast to patients without AFF ( $1.8 \%$ vs. $0.3 \%, p=0.011$, respectively) during a 12-month follow-up [14]. Recently, the Atrial Fibrillation Clopidogrel Trial With Irbesartan for Prevention of Vascular Events (ACTIVE-W) in patients with permanent AF showed no differences between patients with HFpEF and HFrEF with regard to the risk of embolic events and stroke, suggesting a minor role of the extent of LV dysfunction in the increased risk of stroke [81].

Thus, despite recent advancements in the medical, interventional, and device therapy in patients with $\mathrm{HF}$ and $\mathrm{AF}$, acute ischemic stroke remains a severe complication of this disease, with a potentially devastating impact on physical performance, quality of life, and prognosis of HF patients.

\section{The Prevention and Treatment of Stroke in Patients with Heart Failure}

\subsection{Stroke Prevention in Heart Failure with Sinus Rhythm}

The prevention of ischemic stroke includes lifestyle and diet modification, increase in physical activity, as well as pharmacological treatment of comorbidities, such as arterial hypertension, hyperlipidemia, atherosclerosis, and chronic HF. Anticoagulation therapy may require particular contemplation in the absence of $A F$ considering the increased risk of thromboembolic events in patients with HF [82]. A number of clinical trials investigated the impact of anticoagulants and antiplatelet drugs in the prevention of stroke in patients with HF. Previous studies, including Warfarin versus Aspirin in Reduced Cardiac Ejection Fraction (WARCEF), Warfarin and Antiplatelet Therapy in Chronic Heart Failure (WATCH), Heart Failure Long-term Antithrombotic Study (HELAS), and Warfarin/Aspirin Study in Heart Failure (WASH) evaluated the effect of warfarin versus aspirin on the risk of stroke in HFrEF patients with maintained sinus rhythm [35,83-85]. The results of the smallsample WASH and HELAS trials have shown no efficacy of anticoagulant therapy on the composite endpoint of death, stroke, or myocardial infarction in the study patients [86,87]. The WATCH trial showed a reduced risk of ischemic stroke with warfarin (international normalized ratio, INR, of 2.5 to 3.0) compared to aspirin (162 mg once daily), or clopidogrel (75 mg once daily), although this effect was neutralized by an increased risk of bleeding [85]. In the WARCEF trial, a significant reduction in the incidence of ischemic stroke with warfarin (INR of 2.0 to 3.5) compared to aspirin ( $325 \mathrm{mg}$ per day) has been shown only after four years of therapy. However, the rate of major bleeding events significantly increased throughout the treatment in the warfarin group (adjusted rate ratio 2.05 [95\% CI 1.36-3.12], $p<0.001$ ) [86].

Thus, despite the overall reduction in the risk of thromboembolic events, the beneficial effect of warfarin therapy in patients with HFrEF with sinus rhythm could not be confirmed due to an increased risk of bleeding in the study patients $[77,87]$. Therefore, routine administration of warfarin in HF patients with maintained sinus rhythm is currently not recommended $[3,88]$. Acetylsalicylic acid (aspirin) is currently used for the secondary prevention of stroke in HF patients with sinus rhythm [21].

The perspective usage of novel oral anticoagulants (NOACs) has been investigated as a therapeutic approach for stroke prevention in patients with HF [22]. The results of the Rivaroxaban in Patients with Heart Failure, Sinus Rhythm, and Coronary Disease (COMMANDER HF) trial enrolling patients with HFrEF showed no benefit of rivaroxaban ( $2.5 \mathrm{mg}$ twice daily) on top of standard care in the prevention of primary outcome, a composite of all-cause death, myocardial infarction, and stroke [89]. Notably, however, the incidence of all-cause strokes or transitory ischemic attacks (TIA) was reduced by 
$34 \%$ in the rivaroxaban group in a secondary analysis [90]. Again, as in WATCH and WARCEF trials, the increased risk of major bleeding (1.68 [95\% CI 1.18-2.39], $p=0.003$ ) was observed in the COMMANDER HF trial [91]. The Cardiovascular Outcomes for People Using Anticoagulation Strategies (COMPASS) trial, investigating patients with systemic atherosclerotic disease, revealed a $49 \%$ reduction in the relative risk of stroke with rivaroxaban ( $2.5 \mathrm{mg}$ twice daily) plus aspirin (100 $\mathrm{mg}$ once daily) compared to aspirin alone (100 mg once daily). However, the treatment with combined antiplatelet therapy resulted in a $70 \%$ increase in major bleeding events in this patient cohort [92]. The prevalence of HF in this clinical trial was $20 \%$ in each study group.

\subsection{Stroke Prevention in Heart Failure with Atrial Fibrillation}

The main complication of AF apart from hemodynamic dysregulation is a systemic thromboembolic event/cardioembolic stroke. The efficacy of prevention of acute stroke with oral anticoagulant drugs in HF patients with AF has been previously shown [93].

These medications are recommended for patients with a $\mathrm{CHA}_{2} \mathrm{DS}_{2}-\mathrm{VASc}$ score of 2 or more which is used for assessment of stroke risk in patients with $\mathrm{AF}[17,94]$. Currently, there is no conclusive data to administer antithrombotic therapy, oral anticoagulant drugs, or aspirin in the case of a $\mathrm{CHA}_{2} \mathrm{DS}_{2}$-VASc score of 1 , although assessment of thromboembolic risk of each patient is recommended [95]. However, about $15 \%$ of patients with AF and $\mathrm{CHA}_{2} \mathrm{DS}_{2}$-VASc score of 1 may benefit from OACs [95]. Nonetheless, the duration of AF in these patients should be considered and the decision to prescribe these medications in patients with a low score should be individually adjusted $[95,96]$.

The closure of left atrial appendage (LAA), as an alternative therapeutic method, may be considered in high-risk patients with AF who have contraindications to anticoagulants $[97,98]$. The previous clinical trials investigating percutaneous LAA closure showed noninferiority of this procedure to OACs (NOACs or Vitamin K antagonists) in the prevention of cardiovascular and neurological complications $[99,100]$. In addition, the results of the LAARGE (Left-Atrium-Appendage occlude Register-Germany) registry revealed stroke prevention with this interventional method in patients with reduced, mid-range, or preserved LVEF [101]. Currently, several clinical trials are investigating the comparative efficacy of LAA occlusion and OACs in the prevention of cardioembolic events [72,102].

Recently, the Early Treatment of Atrial Fibrillation for Stroke Prevention Trial (EASTAFNET 4) evaluated patients with AF from whom $28 \%$ had stable chronic HF. The findings of this study demonstrated an advantage of the early rhythm control therapy (treatment with antiarrhythmic drugs or AF ablation) compared to the symptomatic treatment of AF (usual care). The study showed a $21 \%$ risk reduction for combined primary outcome consisting of cardiovascular death, stroke, and worsening of HF or CAD during the median follow-up of 5 years [103]. Therefore, several therapeutic options including oral anticoagulation, rhythm control therapy, and LAA closure are available for stroke prevention and need to be individually adjusted in patients with HF and AF (Table 1). 
Table 1. An overview of clinical trials on stroke prevention in heart failure.

\begin{tabular}{|c|c|c|c|c|c|c|c|}
\hline Year & Clinical Trial & No. of Patients & Type of HF & Mean LVEF, \% & Heart Rhythm & Mean FU, Months & Results \\
\hline 2004 & $\begin{array}{c}\text { WASH } \\
\text { (Warfarin/Aspirin } \\
\text { Study in Heart } \\
\text { Failure) [84] }\end{array}$ & 279 & HFrEF & $\leq 35$ & SR & 27 & $\begin{array}{l}\text { No difference in PO (death, nonfatal } \\
\text { myocardial infarction, or nonfatal } \\
\text { stroke) between warfarin vs. aspirin } \\
\text { vs. no antithrombotic treatment }\end{array}$ \\
\hline 2006 & $\begin{array}{l}\text { HELAS (Heart } \\
\text { Failure Long-term } \\
\text { Antithrombotic } \\
\text { Study) [85] }\end{array}$ & 197 & HFrEF & $<35$ & SR & 22 & $\begin{array}{l}\text { No difference in PO (nonfatal stroke, } \\
\text { peripheral or pulmonary embolism, } \\
\text { myocardial re-infarction, } \\
\text { re-hospitalization, exacerbation of } \\
\text { heart failure, or death from any } \\
\text { causes) between aspirin vs. } \\
\text { anticoagulant therapy }\end{array}$ \\
\hline 2009 & $\begin{array}{c}\text { PROTECT AF } \\
\text { (WATCHMAN left } \\
\text { Atrial Appendage } \\
\text { System for Embolic } \\
\text { Protection in Patients } \\
\text { with Atrial } \\
\text { Fibrillation) [104] }\end{array}$ & 707 & Chronic HF & $\geq 30$ & $\mathrm{AF}$ & 48 & $\begin{array}{c}\text { No difference in PO (stroke, } \\
\text { systemic embolism, or } \\
\text { cardiovascular/unexplained death) } \\
\text { between LAA closure vs. warfarin }\end{array}$ \\
\hline 2009 & $\begin{array}{l}\text { WATCH (Warfarin } \\
\text { and Antiplatelet } \\
\text { Therapy in Chronic } \\
\text { Heart Failure) [83] }\end{array}$ & 1587 & HFrEF & $<35$ & $\mathrm{SR} / \mathrm{AF}$ & 21 & $\begin{array}{c}\text { No difference in PO (all-cause } \\
\text { mortality, nonfatal myocardial } \\
\text { infarction, nonfatal stroke) between } \\
\text { warfarin vs. aspirin vs. clopidogrel. } \\
\text { Reduction in strokes but more } \\
\text { hemorrhage in warfarin treatment }\end{array}$ \\
\hline 2012 & $\begin{array}{l}\text { WARCEF (Warfarin } \\
\text { versus Aspirin in } \\
\text { Reduced Cardiac } \\
\text { Ejection } \\
\text { Fraction) [86] }\end{array}$ & 2305 & HFrEF & 25 & SR & 72 & $\begin{array}{l}\text { No difference in PO (death, } \\
\text { ischemic stroke, or intracerebral } \\
\text { hemorrhage) between aspirin vs. } \\
\text { warfarin. Prevention of ischemic } \\
\text { strokes but more major hemorrhage }\end{array}$ \\
\hline
\end{tabular}


Table 1. Cont.

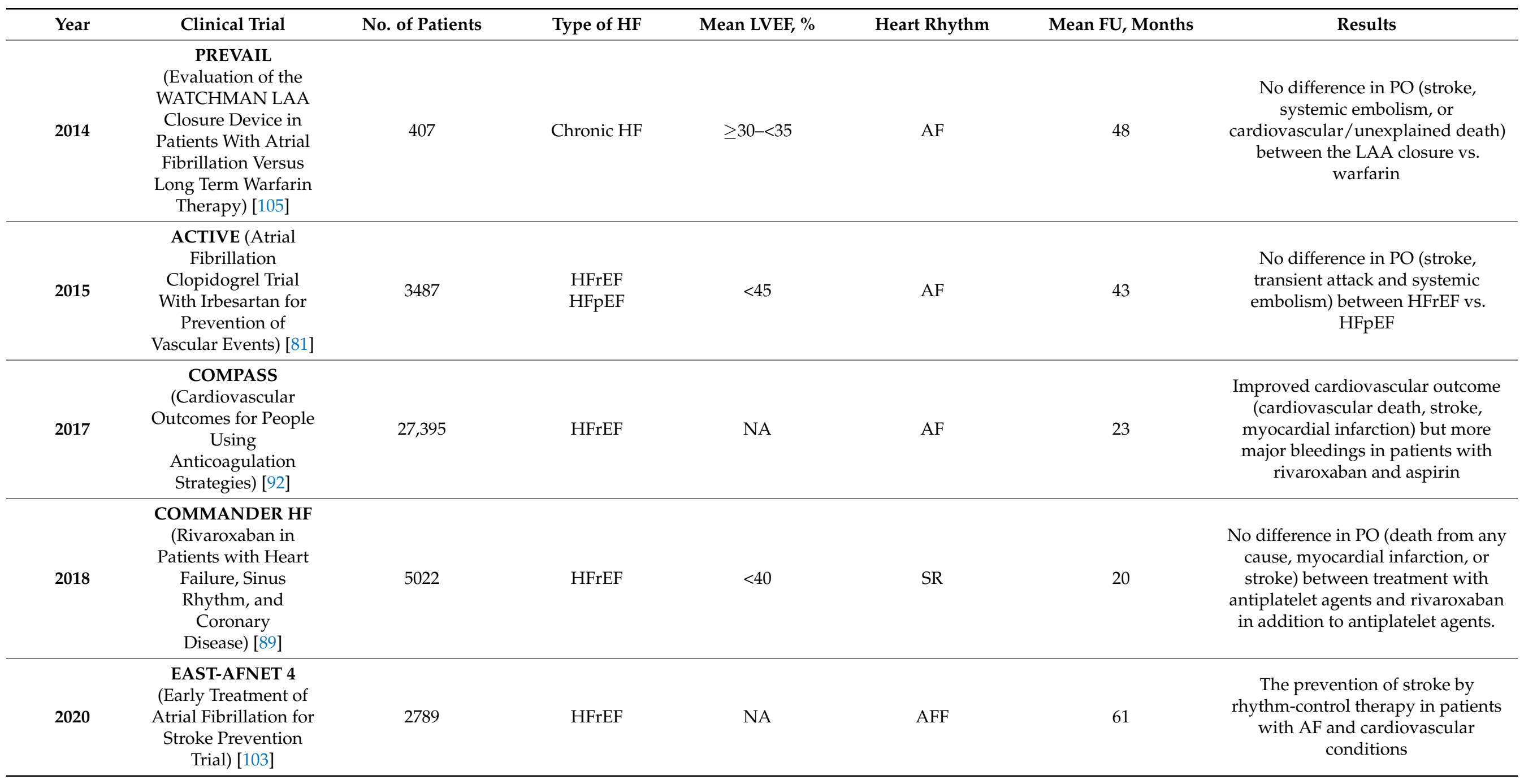


Table 1. Cont

\begin{tabular}{|c|c|c|c|c|c|c|c|}
\hline Year & Clinical Trial & No. of Patients & Type of HF & Mean LVEF, \% & Heart Rhythm & Mean FU, Months & Results \\
\hline 2020 & $\begin{array}{l}\text { LAARGE (Left- } \\
\text { Atrium-Appendage } \\
\text { occlude } \\
\text { Register-Germany } \\
\text { registry) [101] }\end{array}$ & 619 & $\begin{array}{l}\text { HFpEF } \\
\text { HFmrEF } \\
\text { HFrEF }\end{array}$ & $\begin{array}{l}>55 \\
36-55 \\
\leq 35\end{array}$ & $\mathrm{AF}$ & 12 & $\begin{array}{l}\text { The efficacy of LAA closure in the } \\
\text { prevention of stroke in patients } \\
\text { with AF }\end{array}$ \\
\hline 2020 & $\begin{array}{l}\text { PRAGUE-17 (Left } \\
\text { Atrial Appendage } \\
\text { Closure vs. Novel } \\
\text { Anticoagulation } \\
\text { Agents in Atrial } \\
\text { Fibrillation) [100] }\end{array}$ & 402 & Chronic HF & NA & $\mathrm{AF}$ & 21 & $\begin{array}{l}\text { No difference in occurrence of } \\
\text { stroke and increased risk of bleeding } \\
\text { between LAA closure and therapy } \\
\text { with direct oral anticoagulant }\end{array}$ \\
\hline
\end{tabular}

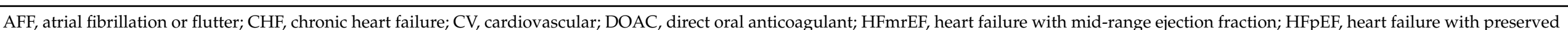

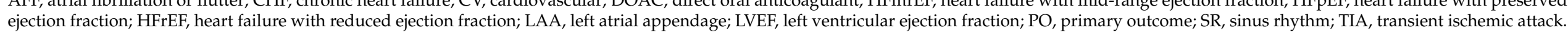




\subsection{Stroke Treatment in HF}

The treatment of patients with acute ischemic stroke should be performed in a stroke unit and, if applicable, with recombinant tissue plasminogen activator (rt-PA) and/or intra-arterial thrombectomy followed by antiplatelet therapy. The decreased therapeutic effect of thrombolysis, a higher risk of systemic embolization of LV thrombi, as well as hypoperfusion-related brain injury may complicate the interventional therapy of acute stroke in patients with HF [21]. However, the findings of a recent study have shown a favorable effect of thrombolysis with rt-PA on stroke outcome disregarding the presence of $\mathrm{HF}$ in this study cohort. In addition, a meta-analysis reported a higher risk of bleeding due to thrombolysis in stroke patients with HF (odds ratio 1.96; [95\% confidence interval 1.30-2.94]) compared to stroke patients without HF [106]. The presence of congestive HF has also been associated with an unfavorable clinical outcome after an intra-arterial thrombectomy compared to patients without HF [107]. Further clinical trials directed to the study of the efficacy of mechanical recanalization treatment in the setting of HF in patients with acute ischemic stroke are warranted.

\section{Conclusions}

HF is a severe clinical syndrome associated with a high mortality and morbidity, particularly among the elderly population worldwide. Stroke is considered one of the major comorbidities of HF requiring timely prevention and treatment. The presence of HF is associated with a poor prognosis in stroke survivors. The development of acute ischemic stroke, mainly induced by a prothrombotic state, the presence of AF, and cerebral hypoperfusion, may lead to acute decompensation of chronic HF and is associated with a physical disability and increased post stroke mortality. The coexistence of acute stroke and chronic HF in many patients leads to both exacerbation of cerebral injury and progression of myocardial dysfunction. Recent clinical trials have shown promising results regarding the administration of NOACs for the prevention of stroke in patients with HF. The understanding of complex pathophysiological mechanisms behind stroke-heart syndrome will contribute to the advancement of knowledge in the diagnosis and management of these pathological conditions. Future studies are required to reveal novel therapeutic strategies to improve the quality of life, functional outcome, and survival of HF patients with acute cerebrovascular diseases.

Author Contributions: Conceptualization, A.B. and N.S.; writing—original draft preparation, A.B. and N.S.; writing-review and editing, A.B. and N.S.; visualization, N.S.; supervision, W.D. All authors have read and agreed to the published version of the manuscript.

Funding: This research received no external funding.

Institutional Review Board Statement: Not applicable.

Informed Consent Statement: Not applicable.

Data Availability Statement: Not applicable.

Conflicts of Interest: The authors have no conflict of interest to declare.

\section{References}

1. Sennfält, S.; Pihlsgård, M.; Petersson, J.; Norrving, B.; Ullberg, T. Long-term outcome after ischemic stroke in relation to comorbidity-An observational study from the Swedish Stroke Register (Riksstroke). Eur. Stroke J. 2020, 5, 36-46. [CrossRef]

2. Siedler, G.; Sommer, K.; Macha, K.; Marsch, A.; Breuer, L.; Stoll, S.; Engelhorn, T.; Dörfler, A.; Arnold, M.; Schwab, S.; et al. Heart Failure in Ischemic Stroke: Relevance for Acute Care and Outcome. Stroke 2019, 50, 3051-3056. [CrossRef]

3. Ponikowski, P.; Voors, A.A.; Anker, S.D.; Bueno, H.; Cleland, J.G.; Coats, A.J.; Falk, V.; González-Juanatey, J.R.; Harjola, V.P.; Jankowska, E.A.; et al. 2016 ESC Guidelines for the diagnosis and treatment of acute and chronic heart failure: The Task Force for the diagnosis and treatment of acute and chronic heart failure of the European Society of Cardiology (ESC). Developed with the special contribution of the Heart Failure Association (HFA) of the ESC. Eur. J. Heart Fail. 2016, 18, 891-975.

4. Branca, L.; Sbolli, M.; Metra, M.; Fudim, M. Heart failure with mid-range ejection fraction: Pro and cons of the new classification of Heart Failure by European Society of Cardiology guidelines. ESC Heart Fail. 2020, 7, 381-399. [CrossRef] 
5. Krishnamurthi, R.V.; Ikeda, T.; Feigin, V.L. Global, Regional and Country-Specific Burden of Ischaemic Stroke, Intracerebral Haemorrhage and Subarachnoid Haemorrhage: A Systematic Analysis of the Global Burden of Disease Study 2017. Neuroepidemiology 2020, 54, 171-179. [CrossRef]

6. Adelborg, K.; Szépligeti, S.; Sundbøll, J.; Horváth-Puhó, E.; Henderson, V.W.; Ording, A.; Pedersen, L.; Sørensen, H.T. Risk of Stroke in Patients With Heart Failure: A Population-Based 30-Year Cohort Study. Stroke 2017, 48, 1161-1168. [CrossRef]

7. Tai, Y.H.; Chang, C.C.; Yeh, C.C.; Sung, L.C.; Hu, C.J.; Cherng, Y.G.; Chen, T.L.; Liao, C.C. Long-Term Risk of Stroke and Poststroke Outcomes in Patients with Heart Failure: Two Nationwide Studies. Clin. Epidemiol. 2020, 12, 1235-1244. [CrossRef] [PubMed]

8. Hamatani, Y.; Nagai, T.; Nakai, M.; Nishimura, K.; Honda, Y.; Nakano, H.; Honda, S.; Iwakami, N.; Sugano, Y.; Asaumi, Y.; et al. Elevated Plasma D-Dimer Level Is Associated With Short-Term Risk of Ischemic Stroke in Patients With Acute Heart Failure. Stroke 2018, 49, 1737-1740. [CrossRef]

9. Pullicino, P.M.; Halperin, J.L.; Thompson, J.L. Stroke in patients with heart failure and reduced left ventricular ejection fraction. Neurology 2000, 54, 288-294. [CrossRef] [PubMed]

10. Sartipy, U.; Dahlström, U.; Fu, M.; Lund, L.H. Atrial Fibrillation in Heart Failure with Preserved, Mid-Range, and Reduced Ejection Fraction. JACC Heart Fail. 2017, 5, 565-574. [CrossRef] [PubMed]

11. Chen, X.; Savarese, G.; Dahlström, U.; Lund, L.H.; Fu, M. Age-dependent differences in clinical phenotype and prognosis in heart failure with mid-range ejection compared with heart failure with reduced or preserved ejection fraction. Clin. Res. Cardiol. 2019, 108, 1394-1405. [CrossRef] [PubMed]

12. Seccia, T.M.; Caroccia, B.; Maiolino, G.; Cesari, M.; Rossi, G.P. Arterial Hypertension, Aldosterone, and Atrial Fibrillation. Curr. Hypertens. Rep. 2019, 21, 94. [CrossRef]

13. Friedman, A.; Chudow, J.; Merritt, Z.; Shulman, E.; Fisher, J.D.; Ferrick, K.J.; Krumerman, A. Electrocardiogram abnormalities in older individuals by race and ethnicity. J. Electrocardiol. 2020, 63, 91-93. [CrossRef]

14. Greene, S.J.; Fonarow, G.C.; Solomon, S.D.; Subacius, H.P.; Ambrosy, A.P.; Vaduganathan, M.; Maggioni, A.P.; Böhm, M.; Lewis, E.F.; Zannad, F.; et al. Astronaut Investigators and Coordinators. Influence of atrial fibrillation on post-discharge natriuretic peptide trajectory and clinical outcomes among patients hospitalized for heart failure: Insights from the astronaut trial. Eur. J. Heart Fail. 2017, 19, 552-562. [CrossRef]

15. Cogswell, R.J.; Norby, F.L.; Gottesman, R.F.; Chen, L.Y.; Solomon, S.; Shah, A.; Alonso, A. High prevalence of subclinical cerebral infarction in patients with heart failure with preserved ejection fraction. Eur. J. Heart Fail. 2017, 19, 1303-1309. [CrossRef]

16. Camm, A.J.; Lip, G.Y.; De Caterina, R.; Savelieva, I.; Atar, D.; Hohnloser, S.H.; Hindricks, G.; Kirchhof, P.; ESC Committee for Practice Guidelines (CPG). 2012 focused update of the ESC Guidelines for the management of atrial fibrillation: An update of the 2010 ESC Guidelines for the management of atrial fibrillation. Developed with the special contribution of the European Heart Rhythm Association. Eur. Heart J. 2012, 33, 2719-2747.

17. Hindricks, G.; Potpara, T.; Dagres, N.; Arbelo, E.; Bax, J.J.; Blomström-Lundqvist, C.; Boriani, G.; Castella, M.; Dan, G.A.; Dilaveris, P.E.; et al. 2020 ESC Guidelines for the diagnosis and management of atrial fibrillation developed in collaboration with the European Association of Cardio-Thoracic Surgery (EACTS). Eur. Heart J. 2021, 42, 373-498. [CrossRef] [PubMed]

18. Kamel, H.; Healey, J.S. Cardioembolic Stroke. Circ. Res. 2017, 120, 514-526. [CrossRef] [PubMed]

19. Adams, H.P., Jr.; Bendixen, B.H.; Kappelle, L.J.; Biller, J.; Love, B.B.; Gordon, D.L.; Marsh, E.E., 3rd. Classification of subtype of acute ischemic stroke. Definitions for use in a multicenter clinical trial. TOAST. Trial of Org 10172 in Acute Stroke Treatment. Stroke 1993, 24, 35-41. [CrossRef]

20. Rücker, V.; Heuschmann, P.U.; O’Flaherty, M.; Weingärtner, M.; Hess, M.; Sedlak, C.; Schwab, S.; Kolominsky-Rabas, P.L. Twenty-Year Time Trends in Long-Term Case-Fatality and Recurrence Rates After Ischemic Stroke Stratified by Etiology. Stroke 2020, 51, 2778-2785. [CrossRef]

21. Clery, A.; Bhalla, A.; Rudd, A.G.; Wolfe, C.D.A.; Wang, Y. Trends in prevalence of acute stroke impairments: A population-based cohort study using the South London Stroke Register. PLoS Med. 2020, 17, e1003366. [CrossRef]

22. Fonseca, A.C.; Ferro, J.M. Cryptogenic stroke. Eur. J. Neurol. 2015, 22, 618-623. [CrossRef] [PubMed]

23. Kamel, H.; Pearce, L.A.; Ntaios, G.; Gladstone, D.J.; Perera, K.; Roine, R.O.; Meseguer, E.; Shoamanesh, A.; Berkowitz, S.D.; Mundl, H.; et al. Atrial Cardiopathy and Nonstenosing Large Artery Plaque in Patients With Embolic Stroke of Undetermined Source. Stroke 2020, 51, 938-943. [CrossRef]

24. Kasner, S.E.; Swaminathan, B.; Lavados, P.; Sharma, M.; Muir, K.; Veltkamp, R.; Ameriso, S.F.; Endres, M.; Lutsep, H.; Messé, S.R.; et al. Rivaroxaban or aspirin for patent foramen ovale and embolic stroke of undetermined source: A prespecified subgroup analysis from the navigate esus trial. Lancet Neurol. 2018, 17, 1053-1060. [CrossRef]

25. Gladstone, D.J.; Sharma, M.; Spence, J.D.; EMBRACE Steering Committee and Investigators. Cryptogenic stroke and atrial fibrillation. N. Engl. J. Med. 2014, 371, 1260. [PubMed]

26. Vemmos, K.; Ntaios, G.; Savvari, P.; Vemmou, A.M.; Koroboki, E.; Manios, E.; Kounali, A.; Lip, G.Y. Stroke aetiology and predictors of outcome in patients with heart failure and acute stroke: A 10-year follow-up study. Eur. J. Heart Fail. 2012, 14, 211-218. [CrossRef] [PubMed]

27. de Peuter, O.R.; Kok, W.E.; Torp-Pedersen, C.; Buller, H.R.; Kamphuisen, P.W. Systolic heart failure: A prothrombotic state. Semin. Thromb. Hemost. 2009, 35, 497-504. [CrossRef]

28. Sbarouni, E.; Bradshaw, A.; Andreotti, F.; Tuddenham, E.; Oakley, C.M.; Cleland, J.G. Relationship between hemostatic abnormalities and neuroendocrine activity in heart failure. Am. Heart J. 1994, 127, 607-612. [CrossRef] 
29. Paolillo, S.; Ruocco, G.; Filardi, P.P.; Palazzuoli, A.; Tocchetti, C.G.; Nodari, S.; Lombardi, C.; Metra, M.; Correale, M.; “Right and Left Heart Failure Study Group" of the Italian Society of Cardiology. Direct oral anticoagulants across the heart failure spectrum: The precision medicine era. Heart Fail. Rev. 2020. [CrossRef]

30. Beggs, S.A.S.; Rørth, R.; Gardner, R.S.; McMurray, J.J.V. Anticoagulation therapy in heart failure and sinus rhythm: A systematic review and meta-analysis. Heart 2019, 105, 1325-1334. [CrossRef]

31. Jug, B.; Vene, N.; Salobir, B.G.; Sebestjen, M.; Sabovic, M.; Keber, I. Procoagulant state in heart failure with preserved left ventricular ejection fraction. Int. Heart. J. 2009, 50, 591-600. [CrossRef] [PubMed]

32. Jekell, A.; Kalani, M.; Kahan, T. The interrelation of endothelial function and microvascular reactivity in different vascular beds, and risk assessment in hypertension: Results from the Doxazosin-ramipril study. Heart Vessels 2019, 34, 484-495. [CrossRef]

33. Scherbakov, N.; Sandek, A.; Martens-Lobenhoffer, J.; Kung, T.; Turhan, G.; Liman, T.; Ebinger, M.; von Haehling, S.; Bode-Böger, S.M.; Endres, M.; et al. Endothelial dysfunction of the peripheral vascular bed in the acute phase after ischemic stroke. Cereb. Dis. 2012, 33, 37-46. [CrossRef]

34. Delewi, R.; Zijlstra, F.; Piek, J.J. Left ventricular thrombus formation after acute myocardial infarction. Heart 2012, 98, 1743-1749. [CrossRef]

35. Di Tullio, M.R.; Qian, M.; Thompson, J.L.; Labovitz, A.J.; Mann, D.L.; Sacco, R.L.; Pullicino, P.M.; Freudenberger, R.S.; Teerlink, J.R.; Graham, S.; et al. Left ventricular ejection fraction and risk of stroke and cardiac events in heart failure: Data from the warfarin versus aspirin in reduced ejection fraction trial. Stroke 2016, 47, 2031-2037. [CrossRef] [PubMed]

36. Lip, G.Y.; Gibbs, C.R. Does heart failure confer a hypercoagulable state? Virchow's triad revisited. J. Am. Coll. Cardiol. 1999, 33, 1424-1426.

37. Massussi, M.; Scotti, A.; Lip, G.Y.H.; Proietti, R. Left Ventricular Thrombosis: New Perspectives on an Old Problem. Eur. Heart J. Cardiovasc. Pharm. 2020. [CrossRef]

38. Klijn, C.J.; Kappelle, L.J. Haemodynamic stroke: Clinical features, prognosis, and management. Lancet Neurol. 2010, 9, 1008-1017. [CrossRef]

39. Pullicino, P.M.; McClure, L.A.; Wadley, V.G.; Ahmed, A.; Howard, V.J.; Howard, G.; Safford, M.M. Blood pressure and stroke in heart failure in the REasons for Geographic And Racial Differences in Stroke (REGARDS) study. Stroke 2009, 40, 3706-3710. [CrossRef]

40. Khan, A.A.; Patel, J.; Desikan, S.; Chrencik, M.; Martinez-Delcid, J.; Caraballo, B.; Yokemick, J.; Gray, V.L.; Sorkin, J.D.; Cebral, J.; et al. Asymptomatic carotid artery stenosis is associated with cerebral hypoperfusion. J. Vasc. Surg. 2020. [CrossRef] [PubMed]

41. Havakuk, O.; King, K.S.; Grazette, L.; Yoon, A.J.; Fong, M.; Bregman, N.; Elkayam, U.; Kloner, R.A. Heart failure-induced brain injury. J. Am. Coll. Cardiol. 2017, 69, 1609-1616. [CrossRef]

42. Leeuwis, A.E.; Hooghiemstra, A.M.; Bron, E.E.; Kuipers, S.; Oudeman, E.A.; Kalay, T.; Brunner-La Rocca, H.P.; Kappelle, L.J.; van Oostenbrugge, R.J.; Greving, J.P.; et al. Cerebral blood flow and cognitive functioning in patients with disorders along the heart-brain axis: Cerebral blood flow and the heart-brain axis. Alzheimers Dement. 2020, 6, e12034.

43. Kalaria, R.N.; Akinyemi, R.; Ihara, M. Stroke injury, cognitive impairment and vascular dementia. Biochim. Biophys. Acta 2016, 1862, 915-925. [CrossRef]

44. Feng, Q. Analysis of the Characteristics and Related Risk Factors of Vascular Dementia After Ischemic Stroke Based on Nuclear Magnetic Resonance. J. Med. Imaging Health Inform. 2021, 11, 445-452. [CrossRef]

45. Mene-Afejuku, T.O.; Pernia, M.; Ibebuogu, U.N.; Chaudhari, S.; Mushiyev, S.; Visco, F.; Pekler, G. Heart Failure and Cognitive Impairment: Clinical Relevance and Therapeutic Considerations. Curr. Cardiol. Rev. 2019, 15, 291-303. [CrossRef] [PubMed]

46. Ozyuncu, N.; Gulec, S.; Kaya, C.T.; Goksuluk, H.; Tan, T.S.; Vurgun, V.K.; Us, E.; Erol, C. Relation of Acute Decompensated Heart Failure to Silent Cerebral Infarcts in Patients With Reduced Left Ventricular Ejection Fraction. Am. J. Cardiol. 2019, 123, 1835-1839. [CrossRef] [PubMed]

47. Haeusler, K.G.; Jensen, C.; Scheitz, J.F.; Krause, T.; Wollboldt, C.; Witzenbichler, B.; Audebert, H.J.; Landmesser, U.; Fiebach, J.B.; Nolte, C.H.; et al. Cardiac Magnetic Resonance Imaging in Patients with Acute Ischemic Stroke and Elevated Troponin: A TRoponin ELevation in Acute Ischemic Stroke (TRELAS) Sub-Study. Cerebrovasc. Dis. Extra 2019, 9, 19-24. [CrossRef]

48. von Rennenberg, R.; Siegerink, B.; Ganeshan, R.; Villringer, K.; Doehner, W.; Audebert, H.J.; Endres, M.; Nolte, C.H.; Scheitz, J.F. High-sensitivity cardiac troponin $\mathrm{T}$ and severity of cerebral white matter lesions in patients with acute ischemic stroke. J Neurol. 2019, 266, 37-45. [CrossRef] [PubMed]

49. Rashid, M.H.; Yaseen, G.; Ghaffar, U.; Khan, A.A.; Kabir, A.; Aisha, A.; Komel, A. Prevalence of Acute Coronary Syndrome and Various Risk Factors in Acute Stroke Patients. Cureus 2020, 12, e9552. [CrossRef] [PubMed]

50. Mochmann, H.C.; Scheitz, J.F.; Petzold, G.C.; Haeusler, K.G.; Audebert, H.J.; Laufs, U.; Schneider, C.; Landmesser, U.; Werner, N.; Endres, M.; et al. Coronary angiographic findings in acute ischemic stroke patients with elevated cardiac troponin: The troponin elevation in acute ischemic stroke (TRELAS) study. Circulation 2016, 133, 1264-1271. [CrossRef]

51. He, L.; Wang, J.; Dong, W. The clinical prognostic significance of hs-cTnT elevation in patients with acute ischemic stroke. BMC Neurol. 2018, 18, 118. [CrossRef] [PubMed]

52. Atanassova, P.A.; Chalakova, N.T.; Dimitrov, B.D. Major vascular events after transient ischaemic attack and minor ischaemic stroke: Post hoc modelling of incidence dynamics. Cerebrovasc. Dis. 2008, 25, 225-233. [CrossRef] [PubMed]

53. Edwards, J.D.; Kapral, M.K.; Lindsay, M.P.; Fang, J.; Swartz, R.H. Young Stroke Survivors with No Early Recurrence at High Long-Term Risk of Adverse Outcomes. J. Am. Heart Assoc. 2019, 8, e010370. [CrossRef] 
54. Alqahtani, F.; Aljohani, S.; Tarabishy, A.; Busu, T.; Adcock, A.; Alkhouli, M. Incidence and outcomes of myocardial infarction in patients admitted with acute ischemic stroke. Stroke 2017, 48, 2931-2938. [CrossRef] [PubMed]

55. Pana, T.A.; Wood, A.D.; Mamas, M.A.; Clark, A.B.; Bettencourt-Silva, J.H.; McLernon, D.J.; Potter, J.F.; Myint, P.K. Norfolk and Norwich Stroke and TIA Register Steering Committee Collaborators, Metcalfe AK, Bowles KM. Myocardial infarction after acute ischaemic stroke: Incidence, mortality and risk factors. Acta Neurol. Scand. 2019, 140, 219-228. [CrossRef]

56. Morris, N.A.; Chatterjee, A.; Adejumo, O.L.; Chen, M.; Merkler, A.E.; Murthy, S.B.; Kamel, H. The risk of Takotsubo cardiomyopathy in acute neurological disease. Neurocritical Care 2019, 30, 171-176. [CrossRef] [PubMed]

57. Jung, J.M.; Kim, J.G.; Kim, J.B.; Cho, K.H.; Yu, S.; Oh, K.; Kim, Y.H.; Choi, J.Y.; Seo, W.K. Takotsubo-Like Myocardial Dysfunction in Ischemic Stroke: A Hospital-Based Registry and Systematic Literature Review. Stroke 2016, 47, 2729-2736. [CrossRef] [PubMed]

58. Scheitz, J.F.; Nolte, C.H.; Doehner, W.; Hachinski, V.; Endres, M. Stroke-heart syndrome: Clinical presentation and underlying mechanisms. Lancet Neurol. 2018, 17, 1109-1120. [CrossRef]

59. Veltkamp, R.; Uhlmann, S.; Marinescu, M.; Sticht, C.; Finke, D.; Gretz, N.; Gröne, H.J.; Katus, H.A.; Backs, J.; Lehmann, L.H. Experimental ischaemic stroke induces transient cardiac atrophy and dysfunction. J. Cachexia Sarcopenia Muscle 2019, 10, 54-62. [CrossRef]

60. Scherbakov, N.; Sandek, A.; Ebner, N.; Valentova, M.; Nave, A.H.; Jankowska, E.A.; Schefold, J.C.; von Haehling, S.; Anker, S.D.; Fietze, I.; et al. Sleep-Disordered Breathing in Acute Ischemic Stroke: A Mechanistic Link to Peripheral Endothelial Dysfunction. J. Am. Heart Assoc. 2017, 6, e006010. [CrossRef] [PubMed]

61. Strittmatter, M.; Meyer, S.; Fischer, C.; Georg, T.; Schmitz, B. Location-dependent patterns in cardio-autonomic dysfunction in ischemic stroke. Eur. Neurol. 2003, 50, 30-38. [CrossRef] [PubMed]

62. Meyer, S.; Strittmatter, M.; Fischer, C.; Georg, T.; Schmitz, B. Lateralization in autononic dysfunction in ischemic stroke involving the insular cortex. Neuroreport 2004, 15, 357-361. [CrossRef]

63. Scherbakov, N.; Barkhudaryan, A.; Ebner, N.; von Haehling, S.; Anker, S.D.; Joebges, M.; Doehner, W. Early rehabilitation after stroke: Relationship between the heart rate variability and functional outcome. ESC Heart Fail. 2020, 7, 2983-2991. [CrossRef]

64. Suzuki, H.; Matsumoto, Y.; Ota, H.; Sugimura, K.; Takahashi, J.; Ito, K.; Miyata, S.; Furukawa, K.; Arai, H.; Fukumoto, Y.; et al. Hippocampal blood flow abnormality associated with depressive symptoms and cognitive impairment in patients with chronic heart failure. Circ. J. 2016, 80, 1773-1780. [CrossRef]

65. Mueller, K.; Thiel, F.; Beutner, F.; Teren, A.; Frisch, S.; Ballarini, T.; Möller, H.E.; Ihle, K.; Thiery, J.; Schuler, G.; et al. Brain Damage With Heart Failure: Cardiac Biomarker Alterations and Gray Matter Decline. Circ. Res. 2020, 126, 750-764. [CrossRef]

66. Abdul-Rahim, A.H.; Perez, A.C.; Fulton, R.L.; Jhund, P.S.; Latini, R.; Tognoni, G.; Wikstrand, J.; Kjekshus, J.; Lip, G.Y.; Maggioni, A.P.; et al. Risk of stroke in chronic heart failure patients without atrial fibrillation: Analysis of the Controlled Rosuvastatin in Multinational Trial Heart Failure (CORONA) and the Gruppo Italiano per lo Studio della Sopravvivenza nell'Insufficienza Cardiaca-Heart Failure (GISSI-HF) Trials. Circulation 2015, 131, 1486-1494. [PubMed]

67. Alberts, V.P.; Bos, M.J.; Koudstaal, P.J.; Hofman, A.; Witteman, J.C.; Stricker, B.H.; Breteler, M.M. Heart failure and the risk of stroke: The Rotterdam Study. Eur. J. Epidemiol. 2010, 25, 807-812. [CrossRef]

68. Burkot, J.; Kopec, G.; Pera, J.; Slowik, A.; Dziedzic, T. Decompensated heart failure is a strong independent predictor of functional outcome after ischemic stroke. J. Card. Fail. 2015, 21, 642-646. [CrossRef] [PubMed]

69. Byun, J.I.; Jung, K.H.; Kim, Y.D.; Kim, J.M.; Roh, J.K. Cardiac function and outcomes in patients with cardio-embolic stroke. PLoS ONE 2014, 9, e95277.

70. Kozdag, G.; Ciftci, E.; Vural, A.; Selekler, M.; Sahin, T.; Ural, D.; Kahraman, G.; Agacdiken, A.; Demirci, A.; Komsuoglu, S.; et al. Silent cerebral infarction in patients with dilated cardiomyopathy: Echocardiographic correlates. Int. J. Cardiol. 2006, 107, 376-381. [CrossRef]

71. Kozdag, G.; Ciftci, E.; Ural, D.; Sahin, T.; Selekler, M.; Agacdiken, A.; Demirci, A.; Komsuoglu, S.; Komsuoglu, B. Silent cerebral infarction in chronic heart failure: Ischemic and nonischemic dilated cardiomyopathy. Vasc. Health Risk Manag. 2008, 4, 463-469. [CrossRef]

72. Häusler, K.G.; Landmesser, U. Verschluss des linken Vorhofohrs bei nichtvalvulärem Vorhofflimmern [Left atrial appendage closure in non-valvular atrial fibrillation]. Herz 2019, 44, 310-314. [CrossRef]

73. Abraham, J.M.; Connolly, S.J. Atrial fibrillation in heart failure: Stroke risk stratification and anticoagulation. Heart Fail. Rev. 2014, 19, 305-313. [CrossRef]

74. Wolf, P.A.; Abbott, R.D.; Kannel, W.B. Atrial fibrillation as an independent risk factor for stroke: The Framingham Study. Stroke 1991, 22, 983-988. [CrossRef]

75. Kim, W.; Kim, E.J. Heart failure as a risk factor for stroke. J. Stroke 2018, 20, 33-45. [CrossRef] [PubMed]

76. Dulli, D.A.; Stanko, H.; Levine, R.L. Atrial fibrillation is associated with severe acute ischemic stroke. Neuroepidemiology 2003, 22, 118-123. [CrossRef]

77. Marini, C.; De Santis, F.; Sacco, S.; Russo, T.; Olivieri, L.; Totaro, R.; Carolei, A. Contribution of atrial fibrillation to incidence and outcome of ischemic stroke: Results from a population-based study. Stroke 2005, 36, 1115-1119. [CrossRef] [PubMed]

78. Pana, T.A.; McLernon, D.J.; Mamas, M.A.; Bettencourt-Silva, J.H.; Metcalf, A.K.; Potter, J.F.; Myint, P.K. Individual and Combined Impact of Heart Failure and Atrial Fibrillation on Ischemic Stroke Outcomes: A Prospective Hospital Register Cohort Study. Stroke 2019, 50, 1838-1845. [CrossRef] [PubMed] 
79. Paciaroni, M.; Agnelli, G.; Falocci, N.; Tsivgoulis, G.; Vadikolias, K.; Liantinioti, C.; Chondrogianni, M.; Bovi, P.; Carletti, M.; Cappellari, M.; et al. Early Recurrence and Major Bleeding in Patients With Acute Ischemic Stroke and Atrial Fibrillation Treated With Non-Vitamin-K Oral Anticoagulants (RAF-NOACs) Study. J. Am. Heart Assoc. 2017, 6, e007034. [CrossRef]

80. Katsanos, A.H.; Parissis, J.; Frogoudaki, A.; Vrettou, A.R.; Ikonomidis, I.; Paraskevaidis, I.; Triantafyllou, N.; Kargiotis, O.; Voumvourakis, K.; Alexandrov, A.V.; et al. Heart failure and the risk of ischemic stroke recurrence: A systematic review and meta-analysis. J. Neurol. Sci. 2016, 362, 182-187. [CrossRef]

81. Sandhu, R.K.; Hohnloser, S.H.; Pfeffer, M.A.; Yuan, F.; Hart, R.G.; Yusuf, S.; Connolly, S.J.; McAlister, F.A.; Healey, J.S. Relationship between degree of left ventricular dysfunction, symptom status, and risk of embolic events in patients with atrial fibrillation and heart failure. Stroke 2015, 46, 667-672. [CrossRef]

82. Schumacher, K.; Kornej, J.; Shantsila, E.; Lip, G.Y. Heart failure and stroke. Curr. Heart Fail. Rep. 2018, 15, 287-296. [CrossRef] [PubMed]

83. Massie, B.M.; Collins, J.F.; Ammon, S.E.; Armstrong, P.W.; Cleland, J.G.; Ezekowitz, M.; Jafri, S.M.; Krol, W.F.; O'Connor, C.M.; Schulman, K.A. Randomized trial of warfarin, aspirin, and clopidogrel in patients with chronic heart failure: The Warfarin and Antiplatelet Therapy in Chronic Heart Failure (WATCH) trial. Circulation 2009, 119, 1616-1624. [CrossRef] [PubMed]

84. Cleland, J.G.; Findlay, I.; Jafri, S.; Sutton, G.; Falk, R.; Bulpitt, C.; Prentice, C.; Ford, I.; Trainer, A.; Poole-Wilson, P.A. The Warfarin/Aspirin Study in Heart failure (WASH): A randomized trial comparing antithrombotic strategies for patients with heart failure. Am. Heart J. 2004, 148, 157-164. [CrossRef]

85. Cokkinos, D.V.; Haralabopoulos, G.C.; Kostis, J.B.; Toutouzas, P.K.; HELAS investigators. Efficacy of antithrombotic therapy in chronic heart failure: The HELAS study. Eur. J. Heart Fail. 2006, 8, 428-432. [CrossRef]

86. Homma, S.; Thompson, J.L.; Pullicino, P.M.; Levin, B.; Freudenberger, R.S.; Teerlink, J.R.; Ammon, S.E.; Graham, S.; Sacco, R.L.; Mann, D.L.; et al. Warfarin and aspirin in patients with heart failure and sinus rhythm. N. Engl. J. Med. 2012, 366, 1859-1869. [CrossRef]

87. Doehner, W.; Ural, D.; Haeusler, K.G.; Čelutkienè, J.; Bestetti, R.; Cavusoglu, Y.; Peña-Duque, M.A.; Glavas, D.; Iacoviello, M.; Laufs, U.; et al. Heart and brain interaction in patients with heart failure: Overview and proposal for a taxonomy. A position paper from the Study Group on Heart and Brain Interaction of the Heart Failure Association. Eur. J. Heart Fail. 2018, 20, 199-215. [CrossRef] [PubMed]

88. Lip, G.Y.; Ponikowski, P.; Andreotti, F.; Anker, S.D.; Filippatos, G.; Homma, S.; Morais, J.; Pullicino, P.; Rasmussen, L.H.; Marin, F.; et al. ESC Task Force. Thrombo-embolism and antithrombotic therapy for heart failure in sinus rhythm. A joint consensus document from the ESC Heart Failure Association and the ESC Working Group on Thrombosis. Eur. J. Heart Fail. 2012, 14, 681-695. [CrossRef]

89. Zannad, F.; Anker, S.D.; Byra, W.M.; Cleland, J.G.F.; Fu, M.; Gheorghiade, M.; Lam, C.S.P.; Mehra, M.R.; Neaton, J.D.; Nessel, C.C.; et al. Rivaroxaban in Patients with Heart Failure, Sinus Rhythm, and Coronary Disease. N. Engl. J. Med. 2018, 379, 1332-1342. [CrossRef]

90. Mehra, M.R.; Vaduganathan, M.; Fu, M.; Ferreira, J.P.; Anker, S.D.; Cleland, J.G.F.; Lam, C.S.P.; van Veldhuisen, D.J.; Byra, W.M.; Spiro, T.E.; et al. A comprehensive analysis of the effects of rivaroxaban on stroke or transient ischaemic attack in patients with heart failure, coronary artery disease, and sinus rhythm: The commander HF trial. Eur. Heart J. 2019, 40, 3593-3602. [CrossRef] [PubMed]

91. He, Y.; Hu, X.; Zhou, S. Successful COMPASS, Disappointing commander HF, What Have We Learned From These Two Trials? J. Cardiovasc. Pharmacol. 2019, 74, 306-307. [CrossRef]

92. Eikelboom, J.W.; Connolly, S.J.; Bosch, J.; Dagenais, G.R.; Hart, R.G.; Shestakovska, O.; Diaz, R.; Alings, M.; Lonn, E.M.; Anand, S.S.; et al. COMPASS Investigators. Rivaroxaban with or without Aspirin in Stable Cardiovascular Disease. N. Engl. J. Med. 2017, 377, 1319-1330. [CrossRef]

93. Ferreira, J.P.; Girerd, N.; Alshalash, S.; Konstam, M.A.; Zannad, F. Antithrombotic therapy in heart failure patients with and without atrial fibrillation: Update and future challenges. Eur. Heart J. 2016, 37, 2455-2464. [CrossRef] [PubMed]

94. January, C.T.; Wann, L.S.; Alpert, J.S.; Calkins, H.; Cigarroa, J.E.; Cleveland, J.C., Jr.; Conti, J.B.; Ellinor, P.T.; Ezekowitz, M.D.; Field, M.E.; et al. 2014 AHA/ACC/HRS guideline for the management of patients with atrial fibrillation: A report of the American College of Cardiology/American Heart Association Task Force on Practice Guidelines and the Heart Rhythm Society. J. Am. Coll. Cardiol. 2014, 64, e1-e76. [CrossRef]

95. Sulzgruber, P.; Wassmann, S.; Semb, A.G.; Doehner, W.; Widimsky, P.; Gremmel, T.; Kaski, J.C.; Savarese, G.; Rosano, G.M.; Borghi, C.; et al. Oral anticoagulation in patients with non-valvular atrial fibrillation and a CHA2DS2-VASc score of 1, a current opinion of the European Society of Cardiology Working Group on Cardiovascular Pharmacotherapy and European Society of Cardiology Council on Stroke. Eur. Heart J. Cardiovasc. Pharmacother. 2019, 5, 171-180. [PubMed]

96. Kaplan, R.M.; Koehler, J.; Ziegler, P.D.; Sarkar, S.; Zweibel, S.; Passman, R.S. Stroke Risk as a Function of Atrial Fibrillation Duration and CHA2DS2-VASc Score. Circulation 2019, 140, 1639-1646. [CrossRef]

97. Baman, J.R.; Mansour, M.; Heist, E.K.; Huang, D.T.; Biton, Y. Percutaneous left atrial appendage occlusion in the prevention of stroke in atrial fibrillation: A systematic review. Heart Fail. Rev. 2018, 23, 191-208. [CrossRef] [PubMed]

98. Ellis, C.R.; Kanagasundram, A.N. Atrial Fibrillation in Heart Failure: Left Atrial Appendage Management. Cardiol. Clin. 2019, 37, 241-249. [CrossRef] 
99. Reddy, V.Y.; Doshi, S.K.; Kar, S.; Gibson, D.N.; Price, M.J.; Huber, K.; Horton, R.P.; Buchbinder, M.; Neuzil, P.; Gordon, N.T.; et al. 5-Year Outcomes after Left Atrial Appendage Closure: From the PREVAIL and PROTECT AF Trials. J. Am. Coll. Cardiol. 2017, 70, 2964-2975. [PubMed]

100. Osmancik, P.; Herman, D.; Neuzil, P.; Hala, P.; Taborsky, M.; Kala, P.; Poloczek, M.; Stasek, J.; Haman, L.; Branny, M.; et al. Left Atrial Appendage Closure Versus Direct Oral Anticoagulants in High-Risk Patients with Atrial Fibrillation. J. Am. Coll. Cardiol. 2020, 75, 3122-3135. [CrossRef]

101. Fastner, C.; Brachmann, J.; Lewalter, T.; Zeymer, U.; Sievert, H.; Borggrefe, M.; Weiß, C.; Geist, V.; Krapivsky, A.; Käunicke, M.; et al. Left atrial appendage closure in patients with a reduced left ventricular ejection fraction: Results from the multicenter German LAARGE registry. Clin. Res. Cardiol. 2020, 109, 1333-1341. [CrossRef] [PubMed]

102. Häusler, K.G.; Endres, M.; Landmesser, U. Left atrial appendage occlusion in patients with nonvalvular atrial fibrillation: Present evidence, ongoing studies, open questions. Med. Klin. Intensivmed. Notfmed. 2020, 115, 107-113. [CrossRef] [PubMed]

103. Kirchhof, P.; Camm, A.J.; Goette, A.; Brandes, A.; Eckardt, L.; Elvan, A.; Fetsch, T.; van Gelder, I.C.; Haase, D.; Haegeli, L.M.; et al. Early Rhythm-Control Therapy in Patients with Atrial Fibrillation. N. Engl. J. Med. 2020, 383, 1305-1316. [CrossRef]

104. Fountain, R.B.; Holmes, D.R.; Chandrasekaran, K.; Packer, D.; Asirvatham, S.; Van Tassel, R.; Turi, Z. The PROTECT AF (WATCHMAN Left Atrial Appendage System for Embolic PROTECTion in Patients with Atrial Fibrillation) trial. Am. Heart J. 2006, 151, 956-961. [CrossRef] [PubMed]

105. Holmes DRJr Kar, S.; Price, M.J.; Whisenant, B.; Sievert, H.; Doshi, S.K.; Huber, K.; Reddy, V.Y. Prospective randomized evaluation of the Watchman Left Atrial Appendage Closure device in patients with atrial fibrillation versus long-term warfarin therapy: The PREVAIL trial. J. Am. Coll. Cardiol. 2014, 64, 1-12. [CrossRef] [PubMed]

106. Whiteley, W.N.; Slot, K.B.; Fernandes, P.; Sandercock, P.; Wardlaw, J. Risk factors for intracranial hemorrhage in acute ischemic stroke patients treated with recombinant tissue plasminogen activator: A systematic review and meta-analysis of 55 studies. Stroke 2012, 43, 2904-2909. [CrossRef]

107. Liebeskind, D.S.; Tomsick, T.A.; Foster, L.D.; Yeatts, S.D.; Carrozzella, J.; Demchuk, A.M.; Jovin, T.G.; Khatri, P.; von Kummer, R.; Sugg, R.M.; et al. Collaterals at angiography and outcomes in the Interventional Management of Stroke (IMS) III trial. Stroke 2014, 45, 759-764. [CrossRef] 